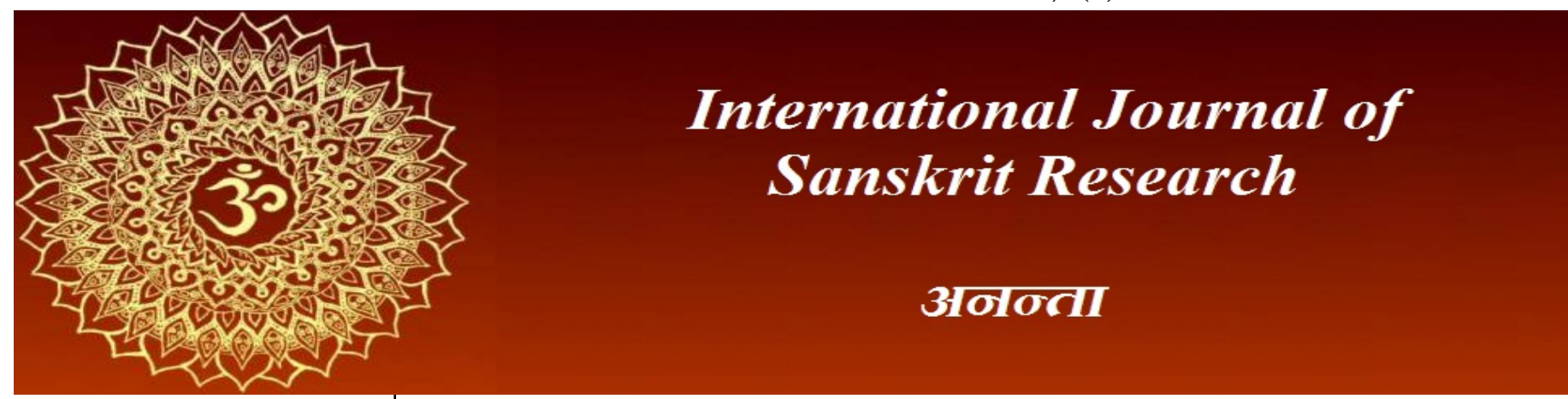

ISSN: 2394-7519

IJSR 2021; 7(3): 114-116

(C) 2021 IJSR

www.anantaajournal.com

Received: 25-03-2021

Accepted: 27-04-2021

Dr. Sukamal Kanti Ghosh Assistant Professor (Selection Grade), Department of Physical Education, Kabi Nazrul Maha Vidyalaya (A Govt. College), Sonamura, Tripura, India

Corresponding Author: Dr. Sukamal Kanti Ghosh Assistant Professor (Selection Grade), Department of Physical Education, Kabi Nazrul Maha Vidyalaya (A Govt. College),

Sonamura, Tripura, India

\section{Inculcation of values in higher education with reference to Pātañjala Yoga sūtra}

\section{Dr. Sukamal Kanti Ghosh}

DOI: https://doi.org/10.22271/23947519.2021.v7.i3b.1409

\section{Abstract}

Pātañjala Yoga philosophy is a valuable asset in the field of value education which may not be evaluated by us of its level in this area. We may only follow the guide lines as it mentioned in its verses through the entire chapters of śastra (book) which will change our entire life style from the disorganized pattern to organize one. Here in this review article by paying due respect and honor to its writer, inculcation of values in higher education has been revisited with reference to his eternal and remarkable work namely Pātañjala Yoga sutra.

Keyword: inculcation, values, higher education, revisited, Pātañjala Yoga sūtra

\section{Introduction}

Values have very vital role in human life and it has different dimension that may be personal, character, ethical, work nișkam karma (duty is for the sake of duty) of Bhagavat Gĩtā which has highest work value\}, family, national, international etc. Emphasis on values is not a new chapter or concept but now in day to day life we are lacking it very frequent in so many occasions which is away from the humanities and it is a matter of concern to the society. That's why thinkers are giving more importance to the sense of values in every where as individual will get a state of real humanities which ultimately leads a peaceful society in the entire world and in this regards India has a vital role from ancient time that is in Veda, Upanișad, Puran, Rāmāyan, Mahābhārat, Ghagvat Gītā, Yoga Darśan etc. where values were highly emphasized in every instance. Among them Pātañjala Yoga sūtra has taken into consideration for this study where to establish the fact, some important verses (sütras) be supported by.

\section{मैत्रीकरुणामुदितोपेक्षाणां सुखदु : खपुण्यापुण्यविषयाणां भावनातश्चित्तप्रसादनम्}

maitrī- karuṇā- muditopekșānāam sukha- duhkha- puṇyāpuṇya- viṣayāṇāṃ bhāvanātaścittaprasādanam - I:33

sukha (pleasure, well being) -------maitrī (friendliness)

You may not be jealous of one's pleasure but to make friendliness with him or her.

duḥkha (misery) ---------karuṇā (compassion)

Compassion of one's misery is an example of true humanity.

punya (virtu,merit) --------- mudita (happiness, joy)

Cultivating attitudes of happiness of one's merit yields a special type of peace.

apunya (sin) -------- upekșā (indifference, forgiveness)

You should pay an attitude of forgiveness towards action of evil person when harmful to oneself. Here Jesus Christ is one of the best examples in this field. A forgiveness attitude is the ultimate one (when someone may be joyful or unpleasant of one's punishment).

ānām (of)

vișaya (subject)

ānām (of)

bhāvanā (repeated thinking or treatment) 
tah (from or through)

citta - prasādana (m) (process of achieving a blissful tranquil state of citta)

By cultivating these are the attitudes in citta (or may be in mind) heartily will awaken values within which leads peace within and in society and it may lead towards world peace if followed properly.

\section{अविद्याउस्मितारागद्वेषाभिनिवेशाः क्लेशाः}

avidyā' smitārāgadveșābhiniveśāh kleśāh - II:3

avidy $\bar{a}=(\mathrm{a}=$ non + vidyā $=$ real knowledge or ultimate knowledge) =non real knowledge

asmitā (a condition where real and unreal may not be identified)

rāga (attachment)

dveșa (hatred)

abhiniveśa $=($ abhi $=$ through + ni $=$ deep down + vesa $=$ entrance) will to live or fear of death

$\bar{a} h$ (suffix of plurality)

kleśa $(\bar{a} h)=k l e s ́ a(\mathrm{~s})($ are $)=$ impurities

Avidyā, asmitā, rāga, dveșa and abhiniveśa are the (five) kleśas

\section{अविद्याक्षेत्रमुत्तरेषां प्रसुत्ततनुविच्छन्नोदाराणाम्}

Avidyā - kṣetram -uttareșām prasupta - tanu -vicchinno udārāṇām - II: 4

avidyā (non real knowledge)

ksetra $(m)=$ field or ground (is)

uttara (eșām) = latter (plu. of)

prasupta (pra =intensely + sputa = dormant) =deeply

dormant

tanu (thinned/feeble/weakened)

vicchinna (interrupted ,occasionally)

udāra (anam) = generously abundant (of plurality)

Avidya $\bar{a}$ is the case to produce other kleśas and are exist in four state of development as dormant, weakened, interrupted (some time present and some time absent) and generously abundant.

\section{अनित्याशुचिदुःखानात्मसु नित्यशुचिसुखात्मख्यातिरविद्या}

anityāśuciduḥkhānātmasu nitya - śucisukhātmakhyātiravidyā $-I I: 5$

anitya $=(a=$ not + nitya $=$ permanent $)$

aśuci $=(a=$ not $+\dot{s} u c i=$ pure $)$ impure

duḥkha (pain)

$\operatorname{anātma~}(s u)=(a=$ not + atma $=$ self $)$ not self (plu. $)$

nitya (permanent)

śuci (pure)

sukha (pleasure)

àtma (self)

khyāti $(h \rightarrow \mathrm{r})=$ knowledge (is)

avidya (not real knowledge)

anitya (not permanent) --------- nitya (permanent)

aśuci (not pure) ------- śuci (pure)

duhkha (pain) -------- sukha (pleasure)

anātma (not self) -------- àtma (self)

Avidya is that where anitya will be understood as nitya, aśuci as śuci, duḥkha as sukha and anātma as ātma.

Hence avidyā will lead to deviation from values ending towards avidyā means approaching towards vidyā (knowledge) and finally ultimate knowledge, means absolute sense of values is cultivated and for destruction of avidyā, Patañjali advocated aștâvangāni or eight limbs of yoga that is yama, niyam, āsana, prāṇāyāma, pratyāhār, dhāraṇā, dhyān and Samāahi. In fact these eight limbs of yoga has a great role towards inculcation of values by which an individual may even achieve the ultimate goal of life that is kaivalya or a state being only oneness.

\section{अहिंसास्त्यास्तेयब्रह्मचर्यापरिग्रहा यमाः}

ahimsā̄- satyāsteya - brahmacaryāparigrahā yamāh - II:30 ahims $\bar{a}=(\mathrm{a}=$ not + hims $\bar{a}=$ injury or violence $)$ non violence satya (truthfulness)

asteya $=(\mathrm{a}=$ non + stey $a=$ stealing $)$ nonstealing

brahmacarya $=($ brahma $=$ Brahman + carya $=$ conduct or behavior) judicious sex restraint

aparigraha $(\bar{a} h \rightarrow \mathrm{a})=(a=$ non + pari $=$ all + grah $=$ taking $)$ non accepting things (plu.)

yama $(\bar{a} h)=$ yama, rules of self restraint (are)

Ahimsā, satya, astya, brahmacarya and aparigraha are the yamas

\section{जातिदेशकालसमयानवच्छिन्ना: सार्बभोमा महात्रतम्}

jāti - deśa - kāla samayānavacchinnāh sārvabhaumā mahāvratam - II:31

jāti (cast or birth in specific circumstances)

deśa (country)

kāla (time)

samaya (occasion)

anavacchinna $(\bar{a} h)=($ an $=$ not + avacchinna $=$ broken $)=$ not broken, not conditioned (plu.)

sarvabhauma $(\bar{a} h \rightarrow a)=($ sārva $=$ all + bhauma =level $)$ applicable to all level (plu)

mahā (great)

$\operatorname{vrata}(m)=$ vow (is)

The observance of yama is to be practiced as the universal or to all level is great vow and not conditioned by birth or country.

\section{वितर्कबाधने प्रतिपक्षभावनम्}

vitarka - bādhane prati - pakșa - bhāvanam - II:33

vitarka (evil tendencies and action)

bādhana $(\rightarrow e)=$ disturbance

pratipakșabhāvana $(\mathrm{m})=($ prati $=$ opposite + pakșa $=$ side + bhavana $=$ repeated thinking or treatment) = trying to cultivate opposite tendency.

In observance of yamas if hindrance may arise through vitarkas (evil tendencies and action) then cultivation of the opposite tendencies must be practiced which is just a work of sense of values only and nothing else.

\section{वितर्का हिंसादयः कृतकारितानुमोदिता लोभक्रोधमोहपूर्वका मृदुमध्याधिमात्रा दुःखाज्ञानानन्तफला इति प्रतिपक्षभावनम्}

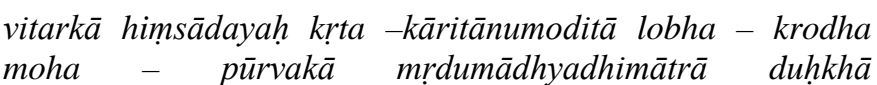
jūānānantaphalā iti prati - pakṣa bhāvanam - II:34 vitark $\bar{a}=$ evil tendencies and action(plu.)

hims $\bar{a}-\bar{a}$ dayah $=$ himssā (causing injuries to other) etc. $k r t a$ (done by oneself)

kārita (got done through other)

anumodita $(\bar{a})=$ approved and sympathized (plurality) 
lobha (greed)

krodha (anger)

moha (infatuation)

pūrvaka $(\bar{a})=$ preceded, caused by (plu.)

mrdu (mild)

madhya (medium)

adhimātra $(\bar{a})=$ extreme degree (plu.)

duhkha (pain)

ajñāna (ignorance)

ananta (end Less)

phala $(\bar{a})=$ result (plu.)

iti (therefore, thus, hence)

prati (opposite)

pakșa (side)

bhàvana $(m)=$ cultivation of tendencies in the mind

Vitarkas are hims $\bar{a}$ and such other things done by one self or got done through other or approved when done by other which may caused through greed or anger or infatuation and which may present in mild, medium and deeply intense in degree which leads towards endless pain and ignorance. Hence try to cultivate tendencies in mind, opposite to the particular vitarkās.

Therefore it may says here that evil tendencies of an individual is the real culprit to him or her and it is needed to take opposite side to that of tendencies which yields result, peace in mind means sense of values in a position.

\section{अहिंसाप्रतिषठायां तत्संनिधो वैरत्याग:}

ahims ā - pratișthāyām tat - sannidhau vaira - tyāgh - II:35

ahimsāa(nonviolence)

pratișthā (yam) = firm establishment (of)

tatsannidhau $=($ tat $=$ him $/$ her + sannidhu $=$ near, surrounding

$+\mathrm{au}=\mathrm{in})\left(\mathrm{in}=\right.$ suff.. $7^{\text {th }}$ loc. Case $)=$ in his vicinity

vaira (enemity)

tyāga $(h)=$ renouncing

The result of firm establishment of ahims $\bar{a}$ (nonviolence) is renouncing or giving up of enmity even by other in his or her vicinity.

\section{सत्यप्रतिषठायां क्रियाफलाश्रयत्वम्}

satya - pratișthāyām kriyā - phalāśrayatvam - II:36

satya (truthfulness)

pratișthā $(y \bar{a} m)=$ firm establishment (of )

kriyāa(action)

phala (fruit, result)

āśraya $($ tavm $)=$ supported by something else, dependence

The result of firm establishment of satya (truthfulness) is dependence of the fruit on action.

\section{अस्तेयप्रतिषठायां सर्वरत्नोपस्थानम्}

asteya - pratișthāyām sarva - ratnopasthānam - II:37

$a$ - steya (non- stealing)

pratișthā $(y \bar{a} m)=$ the firm establishment (of)

sarva (all)

ratna (jewel)

upasthāna $(\mathrm{m})$

The result of firm establishment of asteya (non- stealing) is self-presentation by all jewels before the yogī.

ब्रह्मचर्यप्रतिषठायां वीर्यलाभः
Brahma - carya - pratișthāyā̄m vīrya -lābhah - II:38

Bramha - carya (judicious sex restraint, may be called celibacy, abstinence from sex but fundamentally a life of self discipline conductive for spiritual development)

pratisth $\bar{a}(y \bar{a} m)=$ the firm establishment (of)

vìrya (vigor, vitality)

lābha (ḥ) = gain (is)

The result of firm establishment of brahmacarya is the gain of vigor or vitality.

\section{अपरिग्रहस्थैर्ये जन्मकथन्तासंबोधः}

a - parigraha - sthairya - janma - kathantā saṃbodhah II:39

$a$ - parigraha (non-receiving)

sthairya $(\rightarrow e)=$ stablisation (in)

janma (birth, life)

katha $($ ntā) $=$ purposeful (ness)

sambodha $(h)=$ full knowledge

In the stabilization of aparigraha (non- receiving) results the full knowledge of the purposefulness of an individual life or lives.

The last five sütras (II - 35, 36, 37, 38, 39) are also may be called as five ways (pañcha mārg) to develop the sense of values in a great level of humanity.

\section{Conclusion}

In this review article by presenting selected sūtras from Pātañjala yoga sūtra and after vividly gone through them, this can be concluded that in case of inculcation of values in higher education then our ancient text Pātañjala yoga sūtra (Darśan) may be a leading text to this field. The ideals prescribed in this text if followed properly then in higher education or in lower education or may be in any level of education in relation to inculcation of values in education systems will get an ultimate dimension of holistic approach in humanities where physical, mental, emotional, social and spiritual wellbeing will take place.

\section{References}

1. Karambalkar PV. Pātañjala yoga sūtra, Lonavla: Kaivalyadhama S.M.Y.M Samiti 1978.

2. Premesananda Svami (Edi.), Pātañjala yoga sūtra 2009

3. Vivekananda Svami (Edi:), Raja yoga, Kolkata 2008 